\title{
精巣腫瘍治療後の妊孕能
}

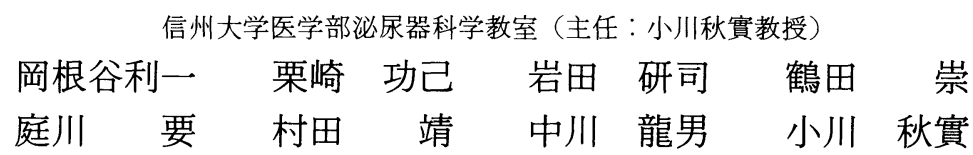

\section{FERTILITY AFTER TREATMENT FOR TESTICULAR TUMOR}

\section{Toshikazu Okaneya, Yoshiki Kurizaki, Kenji Iwata, Takashi Tsuruta, Masashi Niwakawa, Yasushi Murata, Tatsuo Nakagawa and Akimi Ogawa \\ Department of Urology, Shinshu University School of Medicine}

(Director: Prof. A. Ogawa)

Thirty-four patients with stage 1 or stage $2 \mathrm{~A}$ testicular tumor all survived 5 years after the treatment, whereas eighteen patients with stage $2 \mathrm{~B}$ or 3 testicular tumor, including only nonseminomatous tumor, had a 5 -year survival rate of less than $50 \%$.

Spermatogenesis returned to normal in 3 patients surviving 22 months after chemotherapy. Five patients who had undergone retroperitoneal lymph node dissection with division of the inferior mesenteric artery developed impaired ejaculation, whereas 3 patients who had undergone the operation without division of the inferior mesenteric artery had normal ejaculation.

In 17 patients with right testicular tumor metastases were found in the para-aortic, paracaval and interaortocaval lymph nodes. On the other hand, in 4 patients with left testicular tumor metastases were limited to the para-aortic nodes.

These results indicate that impaired spermatogenesis by conventional chemotherapy is reversible in patients with stage 1 or 2 testicular tumor, and patients with stage 1 tumor or stage 2 tumor with localized para-aortic metastases, not involving the inferior mesenteric artery, should undergo retroperitoneal lymph node dissection without division of the inferior mesenteric artery to preserve postoperative fertility.

Key words: testicular tumor, spermatogenesis, ejaculation

\begin{abstract}
要旨: 精巣原発胚細胞腫瘍で, stage IIA 以下の 34 例の 5 年生存率は $100 \%$, stage IIB 以上の18例は全て 非セミノーマで， 5 年生存率は $50 \%$ 以下であった。化学療法後 22 力以上経過し精液検查ができた 3 例 全例は造精能が回復した。後腹膜リンパ節郭清のさい, 下腸間膜動脈を切断した 5 例は全例正常な射精 が得られなかった。一方，同動脈を温存した 3 例では正常射精が保たれた。 stage II 以上の右精巣腫瘍 17 例では，傍大動静脈，大動静脈間リンパ節のいずれにも転移が高頻度にみられ， stage II 以上の左精巣腫 瘍 4 例では転移は傍大動脈リンパ節に限られていた。 以上の結果から，通常量の化学療法で治療可能な stage II 以下では造精能障害は一過性であり，下腸間膜動脈周囲の交感神経を温存する後腹膜リンパ節 郭清は stage I，または stage II のらち左精巣原発で限局性転移があり，しかも下腸間膜動脈周囲に明ら かな転移がみられない時が適応で，これらの症例では妊孕能温存が可能である.

キーワード：精巣腫瘍, 造精能, 射精
\end{abstract}

緒言

精巣腫瘍の治療成績は飛躍的に向上し，転移があっ ても治癒することが多くなっている。その一方, 強力 な抗癌薬投与による造精能障害と後腹膜リンパ節郭清
による射精障害を生じる，根治のため妊孕能を断念せ ざるをえない場合は少なくないが，可能な限り妊孕能 を温存することが望ましい。しかしこの観点から治療 方針を検討した報告は少ない1)。 
我々は精巣腫瘍の治療成績を妊孕能の温存といら観 点から分析し, 化学療法と神経温存後腹膜リンパ節郭 清術の適応について検討したので報告する。

\section{対象と方法}

1978年 1 月から1991年12月までの14年間に信州大学 泌尿器科で治療を行った精巣原発肧細胞腫瘍52例を対 象とした。診断時年齢は 6 力月から 60 歳（中央值が 30 歳) であり，患側は右側が34例，左側が17例，両側 1 例であった。臨床病期分類と組織型の関係を Table 1 に示す。臨床病期分類は, 「辠丸腫瘍取扱い規約」2) 飞従 い, 胸部 X 線撮影, 静脈性尿路造影, 腹部超音波検査 および腹部 CT スキャン，一部の症例では MRIやリ ンパ管造影の結果から判定した。混合型は全て非セミ ノーマ優位で, stage II 以上は全て非セミノーマで あった。

治療法は高位除辠術後, 原発巣の最も優位な組織が セミノーマであるか, 非セミノーマであるかにより異 なった。

stage I のセミノーマは14例に対しては患側腸骨領 域を含めた後腹膜リンパ節に総量 $30 \mathrm{~Gy}$ の放射線照射 を行った。

stage I の非セミノーマ16例に対しては経過観察ま たは予防的化学療法, らち 5 例では後腹膜リンパ節郭 清を行った。

stage II の非セミノーマ9 例のうち 5 例に対しては 化学療法後に後腹膜リンパ節郭清, 2 例に対しては後 腹膜リンパ節郭清後に 2 コースの化学療法を, また 1 例に対しては後腹膜リンパ節郭清のみを, 他の 1 例に 対しては化学療法のみを行った。

stage IIIの非セミノーマ13例に対しては化学療法 により腫揚マーカーが正常化した後に，5例では後腹 膜リンパ節郭清と転移巣切除を行った。

化学療法は stage II 以上の14例に対し, 初期治療と して, 1〜4コース, 平均3.1コース行った. 1989年末 では cisplatin, vinblastin, bleomycin（あるいは pepleomycin) の 3 用 (PVB 療法) $)^{3)}$, 1990年からは cisplatin, etoposideの 2 㓲 (PE 療法) $)^{4)}$ を投与した。

Table 1 Pathological diagnosis and clinical stage

\begin{tabular}{l|c|c|c}
\hline Stage & Seminoma & Non-seminoma & Mixed \\
\hline I & 14 & 10 & 6 \\
IIA & 0 & 2 & 2 \\
IIB & 0 & 4 & 1 \\
III & 0 & 11 & 2 \\
\hline
\end{tabular}

効果判定は,「固形癌化学療法直接効果判定基準 $\rfloor^{5)}$ に従い, 測定可能病変が消失し腫瘍マーカーも正常化 した場合に著効，腫瘍マーカーが正常化しない場合は 測定可能病変が消失しても有効以下とした。

後腹膜リン天゚節郭清では, 腎血管から総腸骨血管分 岐部までの範囲の大動静脈周囲リンパ節と, 患側総腸 骨リンパ節および腹腔内患側精巣動静脈を摘除した。 郭清を行った18例中 6 例（stage I：3 例, stage II： 2 例, stage III：1例)では下腸間膜動脈を温存した。 観察期間は1992年 6 月 1 日の時点で最短 5 力月, 最 長 14 年 8 カ月, 平均 5 年 1 カ月であった.

生存率は Kaplan-Meier 法により算出した ${ }^{6)}$. 臨床 病期別の生存率の有意差は generalized Wilcoxon 法 により判定した。

治療後の妊孕能に関し, 後腹膜リンパ節郭清を施行 した18例について問診と射精後の尿あるいは精液の検 查を行った。

\section{結 果}

Fig. 1 亿臨床病期別の累積生存率を示す. stage I, IIA では全例生存し， 5 年生存率は stage IIBでは $33 \%$, stage III では46\%であり, stage IIA 以下と stage IIB 以上では 5 年生存率に有意差があった。

stage II 以上の22例の治療内容と結果を Table 2 に 示す. 死亡10例は, いずれる stage IIB 以上で, らち 8 例は癌死, 1 例は再発に対する化学療法中の敗血症死, 残る 1 例は再発がない状態での他病死であった。癌死 8 例のうち 3 例は有効な化学療法が確立される以前の 症例であった. stage IIB 以上で初診時の $\beta$-HCG が高 值の 14 例中 6 例が死亡した。

Table 2 Crude survival rates of testicular tumor patients according to treatment modalities

\begin{tabular}{c|c|c|c|c}
\hline Stage & Chemotherapy & RPLND & $\begin{array}{c}\text { Crude } \\
\text { Survival } \\
\text { rate }\end{array}$ & $\begin{array}{c}\text { Survival } \\
\text { Period } \\
\text { (mos) }\end{array}$ \\
\hline (n=30) & $(-)$ & $(-)$ & $20 / 20$ & $14 \sim 173$ \\
& $(+)$ & $(-)$ & $5 / 5$ & $14 \sim 91$ \\
& $(+)$ & $(+)$ & $4 / 4$ & $90 \sim 157$ \\
IIA & $(+)$ & $(+)$ & $1 / 1$ & 103 \\
$(\mathrm{n}=4)$ & $(-)$ & $(+)$ & $3 / 3$ & $72 \sim 125$ \\
IIB & $(+)$ & $(+)$ & $3 / 4$ & $7 \sim 66$ \\
$(\mathrm{n}=5)$ & $(+)$ & $(-)$ & $0 / 1$ & 31 \\
III & $(+)$ & $(+)$ & $2 / 4$ & $15 \sim 31$ \\
$(\mathrm{n}=13)$ & $(+)$ & $(-)$ & $3 / 8$ & $3 \sim 121$ \\
& $(-)$ & $(+)$ & $0 / 1$ & 120 \\
\hline
\end{tabular}

RPLND : retroperitoneal lymph node dissection 
Fig. 1 Survival rates between clinical stages.

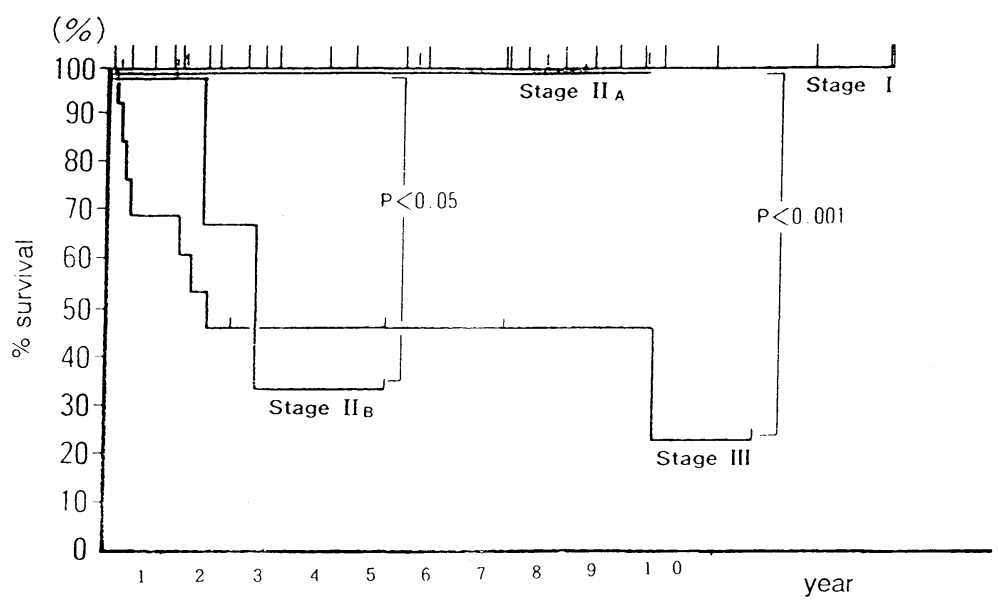

Fig. 2 Distribution of retroperitoneal lymph node metastases in patients with stage II or stage III testicular tumor.

RIGHT TESTICULAR TUMOR

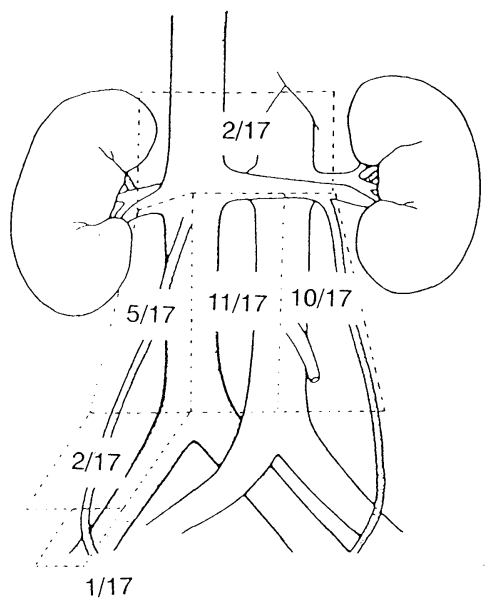

Table 3 Initial response to chemotherapy and outcome

\begin{tabular}{l|c|c}
\hline \multirow{2}{*}{} & \multicolumn{2}{|c}{ No. of patients } \\
\cline { 2 - 3 } & ALIVE & DEAD \\
\hline Complete Response & 4 & 3 \\
Partial Response & 3 & 2 \\
No Change & 0 & 2 \\
\hline
\end{tabular}

導入化学療法に著効を示した 7 例中 3 例が死亡，有 効であった 5 例中 2 例が死亡した。化学療法への反応 と転㷌との間に有意な相関は無かった（Table 3).
LEFT TESTICULAR TUMOR

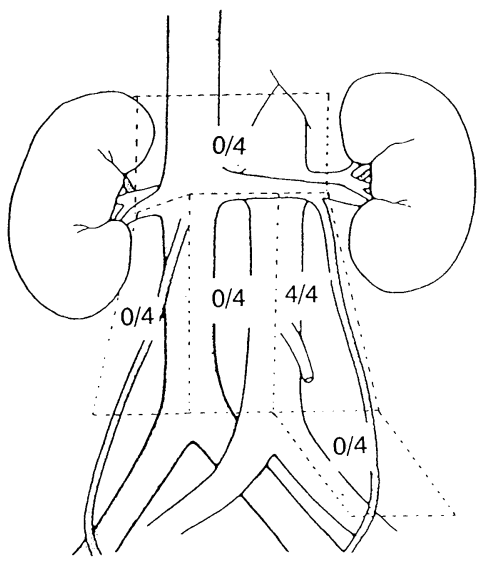

Fig. 2 に stage IIA 以上の22例中, 肺のみに転移し ていた 1 例を除く，21例について治療前の画像診断に よる後腹膜リンパ節転移部位の頻度を示す。リンパ節 は傍大動脈，大動静脈間，傍大静脈，腎血管上り頭側, 精索，総腸骨に分類した。右精巣原発の場合は傍大動 脈，大動静脈間，傍大静脈のいずれにも転移がみられ たが，左精巣原発では傍大動脈領域に限られていた。 鼠径リンパ節転移の 1 例は後腹膜リンパ節の大きな転 移を合併していた。

Table 4 飞臨床病期別の後腹膜リンパ節郭清のさい の下腸間膜動脈の処理を示す。後腹膜リンパ節郭清の 
Table 4 Clinical stage and management of inferior mesenteric artery

\begin{tabular}{l|c|c}
\hline Stage & IMA not divided & IMA divided \\
\hline I & $3(1)$ & 2 \\
IIA & $2(1)$ & 2 \\
IIB & 1 & 3 \\
III & 0 & 5 \\
\hline
\end{tabular}

( ) : No. of pts. whose fertility is confirmed

Table 5 Sexual function of survivors who had been treated for stage II or III testicular tumor

\begin{tabular}{c|c}
\hline Chemotherapy & Impaired spermatogenesis \\
\hline NO & $0 / 1 \%$ \\
YES & $2 / 5$ \\
\hline \multicolumn{2}{|c|}{} \\
\hline RPLND & Impaired ejaculation \\
\hline IMA not divided & $0 / 3 \%$ \\
IMA divided & $5 / 5$ \\
\hline
\end{tabular}

RPLND : retroperitoneal lymph node dissection IMA : inferior mesenteric artery

※: No. of patients affected/No. of patients examined

さいに下腸間膜動脈を温存した 6 例（25歳から38歳） のらち 2 例（30歳 stage I，31歳 stage IIA）では, 術 後に児が誕生した。この 2 例は化学療法は行わなかっ た.

Table 5 に stage II 以上の生存 12 例のらち, 両側除 睪術を行った 1 例を除く11例（18歳から54歳）の術後 の射精能と造精能を示す.下腸間膜動脈を切断した後 に射精能について調査できた 5 例全てに射精障害を生 じた。化学療法終了後 6 力月未満の 2 例 (30歳と 34 歳) は無精子症であった。化学療法後に造精能の回復が確 認された 3 例(19歳, 22歳および31歳)では, cisplatin 総投与量はそれぞれ $370 \mathrm{mg}, 625 \mathrm{mg}, 600 \mathrm{mg}$ で，いず れも治療終了後 25 力月上経過していた。化学療法 3 年後の 1 例（31歳）は児が誕生した。

\section{考察}

自験例の結果では, stage I, stage IIA の精巣腫瘍 は根治するが, stage IIB 以上の進行例で根治し得るの は約半数である。自験例には, 現在の化学療法が確立 する以前の症例を含んでいるため, stage IIB の成績が 不良になっているが，最近の報告では，䋐毛癌成分を 含まない stage IIB の精巣腫瘍で全例に長期生存が得 られている7). 一方, 原発巣に䋐毛癌成分が存在するこ とと治療前の $\beta$-HCG 高值は予後不良因子とされてい
$ろ^{8)}$

従って, stage I, IIA および䋐毛癌を主成分としな いstage IIBの精巣腫瘍は根治性の高い腫瘍なので, 治療に際してはできるだけ妊孕能温存を考慮すべきで あろう。

化学療法による造精能障害は不可避であるが，不可 逆性ではない. 最近, $346 \sim 614 \mathrm{mg} / \mathrm{m}^{2}$ の cisplatin を含 むPVB 療法終了の 4 年後には $100 \%$ の例で造精能が 回復し， 5 年後には $46 \%$ の例で精子数も以前の值に復 すると報告されている ${ }^{9)}$ ，自験例では精液検査をした 症例が少ないが同様の傾向がみられている.すなわち, 通常の化学療法は造精能に一過性障害をもたらすの及 である場合が多いと考兑てよいであろう。

しかし, stage IIB 以上では導入化学療法に奏効して も半数弱に死亡例があるので，さらに強力な化学療法 が必要となることが少なくない，そのよらな場合は造 精能障害が回復する公算は小さくなるが，根治性が最 も重要なので, stage IIB 以上では造精能障害の発生は やむを得ないと考えるべきである。従って，診断時に 既に不妊症であるとされる, 精巣腫瘍患者の約 2 割1) は別として, stage IIA までの症例については造精能を 温存する努力をするべきであろう。

後腹膜リンパ節郭清にもとづく射精障害も妊孕能を 障害する. Donohue, Richie らは, stage I の精巣腫場 に対する神経温存後腹膜リンパ節郭清手術を推奨して いる(1011). すなわち, 下腸間膜動脈を切断せずに，両側 交感神経のうち，下腸間膜動脈起始部の約 1 横指頭側 にある左側の L3 交感神経節とその神経叢を温存する 方法である ${ }^{12)}$.

我々のリンパ節転移部位の検討から，原発巣が右側 の場合は傍大動静脈, 大動静脈間リンパ節郭清が必要 である，原発巣が左側の場合は自験例が少ないので断 定的ではないが, Donohue らの研究結果を参照すると 傍大静脈リンパ節には比較的転移が少ない ${ }^{13)}$. 他方, 転 移が直径 $5 \mathrm{~cm}$ を越える stage IIB 以上の症例は下腸間 膜動脈を切断せずに完全な郭清をすることは困難であ る. 従って, 神経温存後腹膜リンパ節郭清は stage I と, 原発巣が左側で, 下腸間膜動脈周囲に明らかな転 移がなく，転移部位が比較的限局している stage II に 限って適応となるであろう。

われわれの経験によると, stage II では化学療法に より大血管周固に強固な繊維化を生じ, 神経温存後腹 膜リンパ節郭清が困難になる。従って, 射精能の温存 といら点からは, stage II の症例に対しては化学療法 
に先立って郭清手術を行ら方がよいと考える.

stage III では抗癌剂総投与量が多量となるために 造精能が損われる公算が大きく, さらにリンパ節郭清 の範囲が広くて神経温存が難しいので, 当面は妊孕能 の温存は困難である.

\section{文献}

1）古畑哲彦, 小川勝明, 穂坂正彦, 菅原敏道：睪丸腫 瘍患者の治療後の睪丸機能に関する研究. 第 1 編. 治療前後の妊孕能について. 日泌尿会誌, 76, 1022-1028, 1985.

2) 日本泌尿器科学会 -日本病理学会編 : 辠丸腫瘍取 扱い規約, 第 1 版, p. 38-39, 金原出版, 東京, 1984.

3) Einhorn, L.H. and Donohue, J.P.: Cisdiamminedichloroplatinum, vinblastine, and bleomycin combination chemotherapy in disseminated testicular cancer. Ann. Intern. Med., 87, 293-298, 1977.

4) Bosl, G.J., Geller, N.L., Leitner, S.P., Yagoda, A., Golbey, R.B., Scher, H., Vogelzang, N.J., Auman, J., Carey, R., Fair, W.R., Herr, H., Morse, M., Sogani, P. and Whitmore, W. Jr. : A randomized trial of etoposide + cisplatin versus vinblastine+bleomycin + cisplatin + cyclophosphamide+dactinomycin in patients with good-prognosis germ cell tumors. J. Clin. Oncol., 6, 1231-1238, 1988.

5）日本癌治療学会：日本癌治療学会固形がん化学療 法効果判定基準. 日癌治誌, 21, 929-942， 1986.

6）日本癌治療学会：癌規約総論. 第 1 版, p. 18-20, 金原出版, 東京, 1991.

7) Weissbach, L. and Hartlapp, J.H.: Adjuvant chemotherapy of metastatic stage II nonseminomatous testis tumor. J. Urol., 146, 1295-1298, 1991.

8) Hesketh, P.J. and Krane, R.J.: Prognostic assessment in nonseminomatous testicular cancer: Implications for therapy. J. Urol., 144, $1-9,1990$.

9) Hansen, P.V., Trykker, H., Helkjae, P.E. and Andersen, J.: Testicular function in patients with testicular cancer treated with orchiectomy alone or orchiectomy plus cisplatin-based chemotherapy. J. Natl. Cancer Inst., 81, 1246-1250, 1989.

10) Donohue, J.P., Foster, R.S., Rowland, R.G., Bihrle, R., Jones, J. and Geier, G.: Nervesparing retroperitoneal lymph-adenectomy with preservation of ejaculation. J. Urol., 144, 287-292, 1990.

11) Richie, J.P.: Clinical stage 1 testicular cancer: The role of modified retroperitoneal lymphadenectomy. J. Urol., 144, 1160-1163, 1990.

12) Colleselli, K., Poisel, S., Schachtner, W. and Bartsch, G.: Nerve-preserving bilateral retroperitoneal lymphadenectomy: Anatomical study and operative approach. J. Urol., 144, 293-298, 1990.

13) Donohue, J.P., Zachary, J.M. and Maynard, B. R. : Distribution of nodal metastases in nonseminomatous testis cancer. J. Urol., 128, 315-320, 1982.

（1992年 9 月 8 日受理） 